\title{
PENGELOLAAN PERTANIAN DAN SAMPAHNYA: IMPLEMENTASI KULIAH KERJA NYATA DI MASA TATANAN KEHIDUPAN BARU
}

\author{
Shubhi Mahmashony Harimurti ${ }^{1,2}$, Eka Dewi Rahayu', Yebi Yuriandala ${ }^{1,3}$, Muhammad Rizaldi \\ Ilham $^{1}$, Asprilla Surario Hardyastyo ${ }^{1}$, Aldi Muhtadi Billah ${ }^{1}$, Ega $^{1}$, Dian Ayu Pratiwi ${ }^{1}$, Dinar \\ Granita Althoof Sanjaya ${ }^{1}$, Agita Dyah Permatasari ${ }^{1}$
}

${ }^{1}$ Universitas Islam Indonesia

22shubhi.mahmashony@uii.ac.id, ${ }^{3}$ yebi.y@uii.ac.id

\begin{abstract}
Abstrak
Kuliah Kerja Nyata (KKN) Pembelajaran Pemberdayaan Masyarakat (PPM) idealnya adalah terjun langsung ke masyarakat. Kondisi pandemi Corona Virus Disease 2019 (Covid-19) memaksa semua aktivitas termasuk KKN untuk diterapkan pembatasan fisik. Ini disebabkan untuk mengurangi serta mencegah penularan virus yang mudah hancur karena sabun tersebut. Awal Juni 2020, pemerintah mulai membuka beberapa sektor termasuk ekonomi sehingga masyarakat tetap dapat beraktivitas namun harus dengan memperhatikan protokol kesehatan. Ini semua sebagai penanda masa tatanan kehidupan baru. Para petani pun mulai bergairah untuk menggarap sawah maupun ladang mereka termasuk mengelola sampahnya. Pengabdian masyarakat ini bertujuan memberikan pembelajaran dan pemberdayaan masyarakat khususnya para petani dalam mengelola lahan pertanian termasuk sampah yang dihasilkan sehingga bernilai ekonomi. Metode yang diterapkan adalah KKN model blended (campuran) antara dalam jaringan (daring) dan luar jaringan (luring). Media daring yang digunakan adalah Zoom Video Conference dan YouTube sedangkan luring dengan datang langsung ke Desa Ringinputih, Kecamatan Karangdowo, Kabupaten Klaten, Provinsi Jawa Tengah dengan membatasi jumlah mahasiswa yang terlibat. Hasil kegiatan ini adalah para petani mampu mengelola sampah pertanian dengan baik dengan tetap mematuhi protokol kesehatan dan menghasilkan tambahan penghasilan ekonomi meskipun di situasi pandemi.
\end{abstract}

Kata Kunci : KKN PPM, pertanian, sampah, tatatan kehidupan baru

\section{PENDAHULUAN}

KKN atau Kuliah Kerja Nyata merupakan salah satu program wajib yang harus ditempuh oleh mahasiswa sesuai amanat Undang-Undang (UU) No 12 Tahun 2012 tentang Pendidikan Tinggi. Pada saat ini kegiatan $\mathrm{KKN}$ dilakukan dengan metode berbeda dikarenakan pandemi Covid-19 yang sedang mewabah di berbagai negara termasuk di Indonesia, Universitas Islam Indonesia membuat keputusan tetap melakukan kegiatan $\mathrm{KKN}$ namun dengan metode daring atau online. Pada KKN angkatan kali ini program yang dibuat disosialisasikan melalui video edukasi. Tema yang disosialisasikan tentang pelatihan dan pengembangan pupuk untuk pendidikan siswa-siswi kelas XII Sekolah Menengah Atas (SMA) dan sederajat mata pelajaran Biologi. Bertujuan agar siswa-siswi mampu mengetahui cara pengolahan sampah padat atau organic menjadi pupuk kompos yang bernilai ekonomis.

Sampah padat rumah tangga memiliki efek langsung dan tidak langsung pada lingkungan dan kesejahteraan manusia. Efek langsung pada

$$
\text { Lingkungan Hidup dan Bencana }
$$


kesehatan manusia, sehingga menciptakan dampak sosial ekonomi yang signifikan. Efek tidak langsung, yang mempengaruhi sosial ekonomi dan keberlanjutan suatu tempat (Hakami and El-Sayed, 2015).

Pemanfaatan limbah sampah masih belum banyak dilakukan termasuk oleh anak SMA di Desa Ringinputih, Kecamatan Karangdowo, Kabupaten Klaten yang merupakan sasaran KKN PPM ini. Video edukasi diberikan kepada warga terutama pada anak SMA supaya sampah organik dapat memiliki nilai ekonomis serta tidak terbuang sia-sia dan mengakibatkan kerusakan bagi lingkungan sekitar. Tujuan dari program ini yaitu menjelaskan dan melatih kepada siswa dan siswi SMA mengenai cara mengolah sampah organik menjadi pupuk kompos yang memiliki nilai jual sehingga mereka dapat mengetahui dasar-dasar cara pembuatan pupuk kompos mulai dari menentukan lokasi, tempat, serta alat dan bahan yang dibutuhkan untuk pembuatan pupuk kompos.

Jenis dan bahan yang digunakan untuk membuat pupuk organik melalui pengomposan juga beragam dan mudah ditemui.. Mulai dari limbah pertanian maupun non pertanian. Dari pertanian antara lain sisa tanaman (jerami dan brangkasan), sisa pertanian (sekam padi, sisa kulit kacang tanah, ampas tebu), pupuk kandang (kotoran sapi, kerbau, ayam, itik), dan pupuk hijau. Sedangkan contoh dari bahan non pertanian adalah limbah dari pasar-pasar atau rumahtangga dan limbah hasil industri yang biasanya dihasilkan dari industri pangan (Dewi YS dan Treesnowati, 2012).

Dari hasil wawancara terhadap siswa SMA di sebenarnya kebanyakan dari mereka sudah mengetahui tentang hakikat pupuk kompos, namun mereka masih kurang memahami tentang cara pembuatannya yang baik dan benar agar memiliki nilai jual dan bisa dimanfaatkan terutama di era tatanan kehidupan baru ini. Dari hasil kegiatan ini juga dapat disimpulkan bahwa siswa-siswi SMA masih perlu mendapatkan edukasi yang lebih mendalam mengenai tata cara mengelola maupun pengolahan limbah sampah menjadi pupuk kompos agar hasilnya dapat berguna bagi mereka dan lingkungan mereka.

Pengelolaan sampah sebenarnya bukan hanya menjadi tanggungjawab pemerintah daerah saja tetapi menjadi tanggungjawab seluruh lapisan masyarakat. Sebab masyarakat sendiri dengan segala aktifitasnya yang menimbulkan timbunan sampah. Maka diharapkan peran serta masyarakat untuk membantu mengatasi permasalahan ini (Hardiatmi, 2010).

Program ini dipilih dikarenakan sampah organik sangat sulit untuk dikelola sehingga perlu adanya pengenalan sejak dini yaitu pada tingkatan SMA dan sederajat tentang cara mengelola sampah organik menjadi sesuatu yang bernilai salah satunya adalah menjadikannya menjadi pupuk. Program ini disusun dan dibuat dengan harapan dapat menyadarkan siswa dan siswi tentang arti pentingnya mengelola sampah karena pengelolaan sampah masih sangatlah minim khususnya pengelolaan jenis organik yang pengelolaannya sendiri berdampak pada lingkungan yang tidak menyehatkan. Kondisi yang harus dihindari terutama di masa tatanan kehidupan baru.

Sebagian masyarakat berpersepsi bahwa permasalahan sampah hanya berupa permasalahan estetika yaitu bau yang tidak sedap, pemandangan yang terganggu, dan tidak nyaman melewati tempat yang banyak sampahnya. Pencemaran lingkungan sungai hanya disebutkan oleh masyarakat di daerah dekat sungai. Pencemaran lingkungan seperti asap hasil pembakaran sampah dipresepsikan oleh orang yang mengetahui bahwa pengelolaan sampah di TPS ilegal adalah dengan dibakar. Bahaya sampah yang lain seperti mendatangkan penyakit belum menjadi pemikiran masyarakat (Asti MS dan Sulistyowati, 2014).

Penanganan timbulan sampah organik yang berasal dari limbah rumah tangga seperti sisa sayuran, buah-buahan, dan makanan serta sampah pertanian oleh warga cenderung diatasi dengan membakarnya. Kurangnya pengetahuan masyarakat tentang bahaya membakar sampah baik itu di sekitar halaman rumah mereka menyebabkan banyak sekali kerugian dari pihak masyarakat lainnya. Jika dikaji dari pihak masyarakat, akibat dari pembakaran sampah ini kabut asap yang dihasilkan dari pembakaran ini dapat menjadi penyebab Infeksi Saluran Pernapasan Atas (ISPA), udara menjadi tercemar, dan yang paling berbahaya yaitu bisa memicu terjadinya kebakaran.

Selain ISPA, penyakit yang disebabkan oleh timbunan sampah diantaranya adalah diare dan penyakit kulit pada musim hujan. Penyakit tersebut

$$
\text { Lingkungan Hidup dan Bencana }
$$


berawal dari genangan air ditumpukan sampah yang menjadi sarang bagi vektor dan rodent sehingga menyebabkan seseorang terjangkit penyakit. Terutama mayoritas keluarga dalam suatu rumahtangga tidak memiliki tempat pembuangan sampah yang memadai dan hanya dibuang disekitar lingkungan dekat rumah (M Zamzami, 2018).

Sampah yang tidak dikelola dengan baik akan menjadi bermacam-macam fungsinya diantaranya (1) Sarana penularan penyakit terutama pada sampah basah. (2) Kebiasaan lalat. Binatang lalat sangat menyukai tempat kotor dan busuk sebagai rumah dan makananya. (3) Kebiasaan kecoa. Kecoa menyukai tempat lembab dan keadaan gelap. (4) Kebiasaan nyamuk. (5) Kebiasaan tikus. Tikus menyukai tempat-tempat yang terdapat banyak makanan, lembab, dan banyak celah (Suprapto, 2005).

Terdapat banyak pemanfaatan atau pengolahan sampah jika kita mau mengolahnya. Salah satu pemanfaatan sampah adalah dengan mengolah sampah organik menjadi kompos. Selain mengurangi timbulan sampah dan memanfaatkannya, pembuatan kompos juga memberikan nilai ekonomi yang lebih.

\section{METODE}

Dalam pelaksanaan KKN PPM tahap pertama yang ditempuh adalah rekrutmen mahasiswa sebanyak 30 orang yang diminta oleh Dosen Pembimbing Lapangan (DPL) untuk diajukan kepada pihak Universitas dalam hal ini Direktorat Penelitian dan Pengabdian Masyarakat (DPPM). Para mahasiswa tersebut kemudian diberikan pembekalan tentang tema yang hendak dilaksanakan sebagai program KKN PPM. Dalam pelaksanaan KKN PPM ini metode hybrid dipilih dengan perbandingan $60 \%$ daring sedangkan $40 \%$ luring. Pertimbangan utamanya adalah pencegahan penularan Covid-19.

\section{HASIL DAN PEMBAHASAN}

\section{Pengelolaan Sampah Pertanian}

Jika dilihat secara luas pada tahun 2017, Menteri Lingkungan Hidup dan Kehutanan (LHK) Siti Nurbaya mengatakan bahwa Indonesia Darurat Sampah. Terdapat 250.000.000 Penduduk yang tiap orang menghasilkan 0,7 kilogram sampah perhari dengan estimasi tersebut setiap hari Indonesia menghasilkan 175.000 ton sampah dengan perkiraan akan menghasilkan 67.100.000 Ton sampah pada tahun 2019 (Anonim, 2015). Sampah sebanyak itu jika tidak dikelola dengan benar akan memberikan dampak seperti banjir, pencemaran lingkungan, dan tanah tidak subur.

Selain itu Pengolahan sampah di Indonesia masih banyak menggunakan metode 3P (Pengumpulan, Pengangkutan dan Pembuangan) tetapi tidak semua sampah dapat menggunakan metode tersebut, contohnya sampah peternakan dan pertanian. Sampah peternakan yang sering digunakan adalah kotoran dan urin sapi, sampah pertanian adalah sisa hasil panen (Putri, 2019).

Program KKN PPM ini diharapkan dapat menyadarkan arti penting mengelola sampah khususnya sampah organik yang masih sangat minim pengelolaannya.

Peranan pupuk organik dalam peningkatan produktivitas tanah dan tanaman. Dari hasil riset yang dilakukan ditemukan beberapa fakta tentang pupuk di antaranya adalah kadar bahan organik memiliki korelasi positif dengan produktivitas tanaman padi yaitu semakin rendah kadar bahan organik maka semakin rendah produktifitas lahan (Hartatik, 2015). Hal ini menunjukkan bahwa pupuk organik berguna dalam menyuburkan tanah dan membuat tanah menjadi lahan yang produktif. Selain itu dalam jurnal yang sama, penelitian ini menunjukkan fakta lain tentang pupuk yaitu memberikan efek positif dalam jangka panjang selain itu Indonesia adalah negara tropis yang cocok untuk berbagai tanaman. Dikarenakan kondisi ini maka permintaan pupuk semakin meningkat dan hal ini mendorong untuk adanya perkembangan pada industri pupuk organik yaitu industri ini akan membuat lapangan kerja bagi masyarakat (Hartatik, 2015).

Banyak keuntungan yang bisa didapat dari pupuk seperti berkurangnya sampah organik, sebagaimana diketahui bahwa sampah organik merupakan permasalahan yang cukup serius dalam pengelolaannya karena sampah organik jika tidak dikelola dengan baik akan sangat mencemari lingkungan (Hartatik, 2015).

Meski banyak keuntungan yang diberikan dengan adanya pupuk, namun dalam pengelolaannya sendiri perlu pengawasan yang ketat karena hal ini terkait mutu pupuk organik yang diatur dalam peraturan Menteri Pertanian (Mentan) pada Peraturan Mentan No. 70 tahun 2011 tentang Pupuk Organik, Pupuk Hayati, dan Pembenahan Tanah Lingkungan Hidup dan Bencana

575 
perlu ditingkatkan dalam rangka mengantisipasi banyaknya peredaran pupuk organik dalam berbagai jenis, bentuk, dan mutu yang belum terjamin dan teruji kebenarannya, serta dikhawatirkan membahayakan kesehatan dan juga lingkungan (Dewi, dkk, 2012). Jika pengelolaan tidak dilakukan dengan baik dan benar maka pupuk tidak akan memberikan kesuburan dan bahkan bisa membahayakan kesehatan maka dari itu perlu pendidikan atau edukasi sejak dini terkait pupuk.

Dalam pupuk terdapat kunci yang tidak bisa dipisahkan antara satu dengan yang lain. Kunci tersebut adalah tanah, tanaman, dan pupuk. Apabila salah satu dipisahkan secara sengaja maka hasil yang diinginkan nanti tidak akan maksimal karena ketiga hal tersebut saling mendukung antara satu dengan yang lain. Karena pemahaman tentang pupuk tidak terlalu mendetail diajarkan pada sekolah maka terdapat simpang siur yang besar. Baik bahan yang terkandung di dalamnya dan seberapa besar kadarnya. Apabila kadar tidak sesuai dengan yang sudah dijadikan dasarnya atau sesuai takarannya maka hasilnya tidak akan akurat dan akan berpengaruh besar pada tanah serta tanaman yang ditempati pupuk. Karenanya ada baiknya memberikan pemahaman lebih mendalam sebagai bekal untuk memperluas serta menambah wawasan masyarakat tentang dunia perpupukan.

Penjelasan pertama yaitu terkait tanah. Di sini bila berbicara tanah mungkin susah dipahami. Hal ini dikarenakan banyak persoalan yang harus dihadapi. Untuk menuntaskan persoalan tentang tanah dibutuhkan studi yang lebih lama karena tidak mudah dalam mempelajari dan membutuhkan waktu. Bagi yang sudah familiar dengan dunia pertanian, tanah merupakan tempat yang cocok untuk dijadikan pijakan bercocok tanam baik sumber pangan maupun tumbuhan lain. Karena tanah sendiri tersusun atas unsur batuan, mineral, dan bahan organik yang dapat membusuk dalam beberapa kurun waktu. Ada beberapa hal yang sebaiknya diperhatikan dalam ihwal pertanahan ini, antara lain ibarat kata tanah itu menyediakan seluruh kebutuhan pangan yang dibutuhkan oleh tanaman hidup. Dalam tempat itulah tanaman menghasilkan buahnya yang berupa sayuran maupun buah-buahan. Apabila bahan tersebut (tanah) diolah sebaik mungkin, maka hasil yang akan diperoleh akan bagus. Contohnya apabila memasak rendang dengan bumbu rempah yang diproses sendiri dengan bumbu rempah yang instan, pastinya rasanya akan berbeda karena jelas pengolahannya sendiri juga berbeda. Karena itu penting untuk memperhatikan unsur yang diberikan pada tanaman. Hal ini dikarenakan pupuk sekarang banyak yang menyalurkan lewat daun atau langsung disemprotkan berupa cairan, jarang yang diberikan pada tanah. Hal ini disebabkan para petani lebih menyukai pemberian lewat cairan karena praktis dan unsur yang didapatkan tanaman juga lengkap dan para pengolah sawah tersebut mudah untuk mencari pupuk karena sekarang sudah terdistribusi dengan merata dan tersedia dengan banyak merek yang telah resmi terdaftar dan aman.

Kunci kedua yang tidak kalah penting yaitu tentang tanamannya. Hal ini dikarenakan tanaman itu juga makhluk hidup yang memiliki fungsi atas setiap bagian yang terdapat pada tumbuhan. Untuk mempermudah pemahaman maka setiap bagian yang terdapat pada tanaman diberi fungsi yang membantu mendalami arti setiap unsur yang terdapat pada bagian tumbuhan serta yang terdapat pada pupuk. Bicara tentang tanaman tidak terlepas dari pupuk, karena dibutuhkan perawatan yang bagus serta pemberian yang sesuai dengan kebutuhan tanaman agar buah atau apapun yang dihasilkan tanaman tersebut maksimal. Menurut hasil penelitian laboratorium, tanaman hanya terdiri atas dua komponen utama yaitu bahan padan atau kering dan cair. Tidak hanya itu, masih terdapat zat lain yang terdapat di tanaman yang membuat tumbuhan tersebut dapat terus bertahan hidup, hal yang dapat mempermudah pemahaman petani adalah dengan mengamati secara berkala proses pertumbuhan tanaman tersebut. Secara umum hal tersebut biasa dilakukan oleh petani yang sudah berpengalaman pada tanaman, karena petani yang mengamati secara berkala dan konsisten secara periodik juga dapat menguasai sesuatu yang terjadi dan solusinya bagi tanaman yang ditanam. Perlu diberikan pemahaman tentang unsur-unsur yang tidak terdapat pada tanaman dapat menyebabkan perbedaan atau gejala yang tidak diinginkan pada tanaman. Unsur-unsur tersebut adalah seperti Nitrogen (N) yang menyebabkan tanaman akan tumbuh kerempeng dan tidak maksimal, Fosfor (P) yang menyebabkan warna daun akan lebih tua atau mengkilap merah tua, Kalium (K) yang menyebabkan daun akan terlihat gejala mengerut atau keriting terutama pada daun tua

$$
\text { Lingkungan Hidup dan Bencana }
$$

576 
walaupun persebaran bagian tumbuhan yang paling banyak klorofilnya tersebut yang rusak sering tidak merata.

Kunci yang ketiga merupakan pupuk, karena ibarat kata seperti stimulus tambahan agar tanaman yang ditanam bisa tumbuh lebih baik lagi melebihi batas standar tumbuhan tersebut. Tidak sedikit petani yang merasakan kekurangan apabila tidak memberikan pupuk pada tanaman yang ditanam. Apabila diibaratkan seperti makan seperti lauk tanpa nasi serasa kurang nikmat. Pupuk sendiri pada Desa Ringinputih, Kabupaten Klaten yang merupakan sasaran KKN PPM sendiri masih jarang ditemui terutama untuk pengolahan di desanya sendiri. Warga desa lebih memilih mengeluarkan uang karena tidak memahami proses pembuatan pupuk dari bahan-bahan yang sudah ada. Perlu diberikan pemahaman pada warga desa tentang cara pembuatan pupuk baik dari bahan bekas atau sampah organik maupun nonorganik. Untuk sampah organik sendiri bisa diolah sendiri dengan membuat seperti tong yang diberi sekat membatasi sampah dan cairan yang dihasilkan yang nantinya menjadi pupuk cair, untuk bahan pembuatan pupuk cair bahan organik cukup mudah yaitu dengan memberikan efektor pada sampah sisa makanan seperti buah-buahan atau sayur-sayuran lalu ditunggu selama kurang lebih 1 bulan untuk menghasilkan cairan pupuk yang maksimal. Cairan tersebut bisa langsung dituangkan pada tanaman yang dimiliki petani serta bisa menghemat biaya yang dikeluarkan warga desa untuk membeli pupuk yang tersedia di pasar dan mungkin harganya lebih mahal daripada biaya yang dikeluarkan untuk membuat pupuk sendiri dengan cara yang sudah disebutkan sesuai deskripsi di atas.

Hal tersebut perlu dikembangkan karena kompos merupakan salah satu pupuk organik yang digunakan pada pertanian untuk mengurangi penggunaan zat penyubur dari anorganik. Penggunaan kompos dapat memperbaiki sifat fisik tanah dan mikrobiologi tanah (Syam, 2003). Kompos memiliki kandungan unsur hara seperti nitrogen dan fosfat dalam bentuk senyawa kompleks argon, protein, dan humat yang sulit diserap tanaman (Setyotini et al., 2006). Berbagai upaya untuk meningkatkan status hara dalam kompos telah banyak dilakukan, seperti penambahan bahan alami tepung tulang, tepung darah kering, kulit batang pisang, dan biofertilizer (Simanung kalit et al., 2006).
Pengomposan merupakan salah satu metode pengelolaan sampah organik yang bertujuan mengurangi dan mengubah komposisi limbah menjadi produk yang bermanfaat. Menurut Faatih (2012), pengomposan merupakan salah satu proses pengolahan limbah organik menjadi material baru seperti halnya humus. Kompos umumnya terbuat dari sampah organik yang berasal dari dedaunan dan kotoran hewan, yang sengaja ditambahkan agar terjadi keseimbangan unsur nitrogen dan karbon sehingga mempercepat proses pembusukan dan menghasilkan rasio $\mathrm{C} / \mathrm{N}$ yang ideal. Standar kualitas kompos dikatakan ideal jika memenuhi standar kriteria seperti tercantum dalam SNI 19-7030-2004 (BSN 2004).

Teknologi pembuatan pupuk kompospun sudah sangat beragam mulai dari yang sederhana sampai yang canggih. Mulai dari sistem terbuka hingga tertutup didalam reaktor dengan menggunakan injeksi udara. Reaktor yang digunakanpun beragam mulai dari reaktor tegak, horizontal, dan miring (Sahwan, 2012).

Program Media Bidang Pembelajaran merupakan salah satu program dari KKN PPM. Pada program ini menghasilkan video pembelajaran tentang Pelatihan dan Pengembangan Pupuk untuk Pendidikan Siswa XII SMA dan Sederajat pada Mata Pelajaran Biologi. Video yang berdurasi 8 menit 39 detik dibuat dengan tujuan untuk membantu pelajar tingkat SMA dan sederajat dalam belajar mengenai pembuatan pupuk. Selain itu dengan adanya video ini diharapkan siswa kelas XII SMA dan sederajat memahami arti penting pengelolaan sampah. Video yang dibuat oleh mahasiswa KKN PPM berisi tentang klasifikasi sampah, komposisi pembuatan pupuk kompos, proses pembuatan pupuk, memilih lokasi yang cocok untuk produksi, faktor penunjang, manfaat adanya pupuk kompos.

Pada tahap prapelaksanaan program bidang pembelajaran ini, mahasiswa melakukan rapat zoom dan menunjuk penanggung jawab terkait agenda ini, kemudian mahasiswa melakukan diskusi membahas ide dan mengidentifikasi hal apa yang cocok untuk siswa SMA khususnya kelas XII dan hal tersebut harus membahas mengenai pengelolaan sampah. Setelah menemukan judul dan ide yang tepat, gagasan tersebut dibagi menjadi beberapa subbab kemudian mahasiswa dibagi untuk membuat materi yaitu tiap dua mahasiswa akan membahas satu subbab. Setelah itu mahasiswa melakukan diskusi

$$
\text { Lingkungan Hidup dan Bencana }
$$


terkait materi yang telah dibuat dan telah disetujui oleh penanggung jawab pembuat storyboard. Setelah storyboard dibuat, kemudian dikirim ke Dosen Pembimbing Lapangan (DPL) kemudian meminta evaluasi mengenai kesesuaian dengan program yang dilaksanakan.

Berikut storyboard dari video bidang pembelajaran:

Tabel 1. Storyboard video pembelajaran

\begin{tabular}{|c|c|}
\hline Time Frame & Isi \\
\hline $00.00-01.14$ & $\begin{array}{l}\text { Intro \& Pengenalan Anggota } \\
\text { Unit }\end{array}$ \\
\hline $01.15-01.43$ & $\begin{array}{l}\text { Pengenalan Program } \\
\text { Materi : "Edukasi tentang } \\
\text { pembuatan dan } \\
\text { pengembangan pupuk } \\
\text { kompos untuk anak SMA } \\
\text { sederajat" }\end{array}$ \\
\hline $01.44-02.02$ & $\begin{array}{l}\text { Menjelaskan klasifikasi } \\
\text { sampah dalam pembuatan } \\
\text { pupuk. }\end{array}$ \\
\hline $02.03-03.39$ & $\begin{array}{l}\text { Menjelaskan Komposisi alat } \\
\text { dan bahan dalam pembuatan } \\
\text { pupuk kompos. }\end{array}$ \\
\hline $03.40-05.18$ & $\begin{array}{l}\text { Menjelaskan tentang proses } \\
\text { pembuatan pupuk kompos }\end{array}$ \\
\hline $05.19-06.10$ & $\begin{array}{l}\text { Menjelaskan lokasi yang } \\
\text { cocok }\end{array}$ \\
\hline $06.11-07.20$ & $\begin{array}{l}\text { Menjelaskan faktor-faktor } \\
\text { penunjang dan manfaat }\end{array}$ \\
\hline $07.21-07.24$ & Kesimpulan \\
\hline $07.25-08.16$ & Testimoni \\
\hline $08.17-08.24$ & Clossing \\
\hline $08.25-08.39$ & Credit \\
\hline
\end{tabular}

Pada tahap pelaksanaan ini mahasiswa menjalankan program yang telah disusun dalam storyboard. Masing - masing mahasiswa mengambil video sesuai dengan materi dari subbab yang telah dibuat. Pengambilan video dilakukan di beberapa tempat dalam lingkungan Kampus Universitas Islam Indonesia. Kemudian penanggung jawab mengevaluasi video dan melakukan editing.

Tahap pascapelaksanan ini mahasiswa mengevaluasi video yang telah dibuat oleh penanggung jawab dan melakukan diskusi dengan DPL untuk mengevaluasi kesesuaian dengan program yang telah dilaksanakan. Jika terdapat beberapa bagian dari video yang masih kurang baik, dilakukan perbaikan oleh penanggung jawab.

\section{Pemberdayaan kepada Petani di Era Tatanan Kehidupan Baru}

Penyuluhan mengenai protokol kesehatan di era tatanan kehidupan baru saat ini sebenarnya telah banyak dilakukan oleh berbagai pihak terutama pemerintah sendiri. Berdasarkan pengamatan langsung di Desa Ringinputih, Kabupaten Klaten yang merupakan sasaran KKN PMM masih terdapat warga khususnya kelompok petani yang kurang memperhatikan protokol kesehatan seperti penggunaan masker dan menerapkan physical distancing. Tujuan dari kegiatan ini untuk meningkatkan kepatuhan warga khususnya kelompok petani terhadap protokol kesehatan. Metode pelaksanaan yang digunakan dalam kegiatan ini yaitu sosialisasi baik secara online maupun offline.

Kurangnya kesadaran untuk menggunakan masker, mencuci tangan atau menggunakan handsanitizer, serta menerapkan physical distancing dapat membentuk pola kebiasaan yang tidak baik serta dapat membahayakan kesehatan diri sendiri maupun orang lain. Kegiatan penyuluhan ini diharapkan mampu meningkatkan kepatuhan warga khususnya kelompok petani terhadap protokol kesehatan. Hal tersebut mampu memutus rantai penyebaran Covid-19.

Program ini dipilih dikarenakan adanya pandemi Covid-19 yang melanda seluruh dunia termasuk Indonesia sehingga memengaruhi masyarakat dalam berakitivitas. Dikarenakan adanya pandemi Covid19 dan aktivitas sehari-hari harus dilakukan maka muncul istilah era tatanan kehidupan baru. Pemahaman tentang tatanan kehidupan baru ini penting karena dengan memberikan pengertian yang benar diharapkan dapat mencegah penularan virus corona di antara masyarakat saat beraktivitas. Desa Ringinputih sebagai sasaran KKN PPM merupakan salah satu yang berada di kawasan zona merah selama pengabdian masyarakat dilaksanakan. Hal ini dikarenakan kebijakan yang sedikit longgar dalam beraktivitas. Warga harus tetap waspada dalam beraktivitas. Mayoritas penduduk berprofesi sebagai petani yang tidak bisa dilakukan dengan cara Work from Home (WfH) oleh karena itu program ini dipilih, disusun, dan dibuat dengan harapan bisa membantu warga dalam menjalankan aktivitas dengan tetap menjunjung tinggi protokol kesehatan.

Setiap hari terdapat peningkatan kasus yang sangat memengaruhi banyak aspek dalam beraktivitas. Dikarenakan belum ditemukannya

$$
\text { Lingkungan Hidup dan Bencana } 578
$$


vaksin untuk virus corona maka Indonesia menerapkan sebuah sistem tatanan kehidupan baru dalam beraktivitas yang diharapkan dapat mencegah penularan virus pada saat masyarakat beraktivitas yang rutinitas ini tidak bisa dilakukan secara online.

Selain berdampak pada kesehatan fisik, beberapa studi menunjukkan bahwa adanya virus corona berdampak juga pada kesehatan psikis (Park, 2020). Hal ini diakibatkan efek berantai yang disebabkan oleh adanya virus corona seperti adanya jaga jarak sosial dan karantina membuat seseorang merasa kesepian secara berkepanjangan. Hal ini memengaruhi kesehatan psikis seseorang menjadi buruk (Rogers and others, 2020). Selain itu efek berantai seperti kehilangan pekerjaan selama pandemi membuat finansial seseorang menjadi tidak stabil (Park, 2020). Fakta ini juga menjadi pendorong KKN PPM ini dilaksanakan untuk meningkatkan taraf hidup masyarakat di tengah pandemi. Efek dari terpengaruhnya kesehatan psikis selama pandemi korona adalah menurunnya kualitas tidur seseorang yang hal ini akan membuat seseorang menjadi mudah lelah dan menjadi lebih stress (The Lancet, 2020). Beberapa studi menunjukkan membaca berita terkait virus korona dapat memberikan kecemasan dan seseorang dapat merasa terancam ( $\mathrm{Wu}$ and others, 2020). Dampak dari berkurangnya kesehatan psikis secara berkepanjangan dapat memengaruhi imunitas tubuh, kesehatan fisik, kesehatan mental dan bahkan meningkatnya perasaan untuk menyakiti diri sendiri (Minihan and others, 2020). Hal ini memengaruhi kualitas hidup secara umum. Semakin tinggi tingkat stress yang dirasakan seseorang akan membuat kesehatan fisik menjadi memburuk seperti memicu penyakit yang berhubungan dengan jantung, gangguan tidur, sakit perut, dan sakit kepala (Finsterer and Stollberger, 2020).

\section{KESIMPULAN}

KKN PPM di era tatanan kehidupan baru masih dapat berjalan dengan baik. Prinsipnya adalah aktivitas penggerak ekonomi bisa terlaksana dan pastinya tetap berpegang pada protokol kesehatan. Implikasi dari KKN PPM ini adalah adalah para petani mampu mengelola sampah pertanian dengan baik dengan tetap mematuhi protokol kesehatan dan menghasilkan tambahan penghasilan ekonomi meskipun di situasi pandemi. Pemahaman mereka pun meningkat seiring dengan pemberdayaan yang dilakukan oleh mahasiswa melalui kegiatan $\mathrm{KKN}$ PPM ini.

\section{UCAPAN TERIMA KASIH}

Kegiatan KKN PPM ini dapat terlaksana dengan baik berkat bantuan dari Direktorat Riset dan Pengabdian Masyarakat, Deputi Bidang Penguatan Riset dan Pengembangan, Kementerian Riset dan Teknologi/Badan Riset dan Inovasi Nasional sesuai dengan Kontrak 1 Nomor: 102/SP2H/PPM/DRPM/2020, Tanggal 12 Februari 2020. Didukung pula oleh Direktorat Penelitian dan Pengabdian Masyarakat (DPPM) UII. Ucapan terima kasih layak diberikan kepada kedua belah pihak.

\section{REFERENSI}

Asti, M.S. dan Sulistyowati. (2014). Keberadaan TPS Legal dan TPS Ilegal di Kecamatan Godean Kabupaten Sleman. Jurnal Kesehatan Masyarakat. 9(2), 122-130.

BSN [Badan Standarisasi Nasional]. (2004). Spesifikasi Kompos dari Sampah Organik Domestik. SNI 19- 7030-2004.

Dewi, T., Anas, I., Nursyamsi, D., Penelitian, B., Pertanian, L., Raya, J., Km, J., Pos, K., Jawa, P., Penelitian, B., Lahan, P., Jl, R., Karet, K., Tabat, L., \& Pos, K. (2012). Evaluasi Kualitas Pupuk Organik Yang Beredar Di Pulau Jawa Berdasarkan Permentan No. 70/Sr. 140/10 Tahun 2011 Quality Evaluation Organic Fertilizers Marketed in Java Island Based on the Ministrial Agriculture Regulation No . 70 / Permentan/SR . 14. 14(70), 79 83.

Dewi, Y.S., Tresnowati. (2012). Pengelolaan Sampah Skala Rumahtangga Menggunakan Metode Composting. Jurnal Ilmiah Fakultas Teknik LIMIT'S. 8(2): 35-48.

Faatih M. (2012). Dinamika Komunitas Aktinobakteria Selama Proses Pengomposan. Jurnal Kesehatan 15(3):611-618.

Finsterer, J dan Stollberger, C. (2020). Causes Of Hypogeusia/ Hyposmia in SARS-CoV Infected Patiens. Journal of Medical Virology Volume 92, Issue 10.

Hakami, B. A., and El-Sayed, S. A. S. (2015). Household Solid Waste Composition and Management in Jeddah City, Saudi Arabia: A Planning Model. International Research Journal of Environmental Sciences. Vol 4(1):1-10

$$
\text { Lingkungan Hidup dan Bencana }
$$


Hardiatmi S. (2010). Pendukung Keberhasilan Pengelolaan Sampah Kota. INNOFARM. Jurnal Inovasi Pertanian. 10(1), 50-66.

Hartatik, W., Husnain, H., \& Widowati, L. R. (2015). Peranan pupuk organik dalam peningkatan produktivitas tanah dan tanaman.

Putri, I. D. (2019, June 30). Pengolahan Sampah Peternakan dan Pertanian dengan Metode Pengomposan.

https://doi.org/10.31227/osf.io/7vkm2

Sahwan F.L. (2012). Potensi Sampah Kota Sebagai Bahan Baku Pembuatan Kompos Untuk Mendukung Kebutuhan Pupuk Organik dalam Rangka Memperkuat Kemandirian Pangan. Jurnal Teknik Lingkungan. 13(2): 193-201.

Setyotini, D. R., \& Saraswati, dan Anwar, E. K. (2006). Kompos. Jurnal Pupuk Organik dan Pupuk Hayati. 2(3), 11-40.

Simanungkalit, R. D. M., Didi, A. S., Rasti, S., Diah, S., \& Wiwik, H. (2006). Pupuk Organik dan Pupuk Hayati. Balai Besar Penelitian dan Pengembangan Sumberdaya Lahan Pertanian. Jawa Barat.

Suprapto. (2005). Dampak Masalah Sampah Terhadap Kesehatan Masyarakat. Jurnal Mutiara Kesehatan. 1(2), 1-4.

Syam, A. (2003). Efektivitas Pupuk Organik dan Anorganik terhadap Produktivitas Padi di Lahan Sawah. Jurnal Agrivigor 3 (2), 232-244.
Zamzami M., dkk (2018). Analisis Pengelolaan Sampah Pada Masyarakat Desa Disanah Kecamatan Sreseh Kabupaten Sampang. Jurnal Kesehatan Lingkungan 10(4): 368-375. 